\title{
Responses of Marigold Cultivars to Saline Water Irrigation
}

\author{
Youping Sun ${ }^{1}$, Genhua $\mathrm{Niu}^{2,5}$, Christina Perez ${ }^{2}$, \\ H. Brent Pemberton ${ }^{3}$, and James Altland ${ }^{4}$
}

AdDitional IndeX wORDs. Tagetes patula, Tagetes evecta, soil plant analysis development, cluster analysis, salinity

Summary. Marigolds (Tagetes sp.) are ornamental plants with fine-textured, dark green foliage, and yellow, orange, or bicolored flowers. The relative salt tolerance of eight marigolds ['Discovery Orange', 'Discovery Yellow', 'Taishan Gold', 'Taishan Orange', and 'Taishan Yellow' african marigold (Tagetes evecta); 'Hot Pak Gold', 'Hot Pak Orange', and 'Hot Pak Yellow' french marigold (Tagetes patula)] was evaluated in a greenhouse experiment. Plants were irrigated weekly with nutrient solution at an electrical conductivity (EC) of $1.2 \mathrm{dS} \cdot \mathrm{m}^{-1}$ (control) or saline solutions at an EC of 3.0 or $6.0 \mathrm{dS} \cdot \mathrm{m}^{-1}$ (EC 3 or EC 6). Marigold plants began to show foliar salt damage (leaf burn and necrosis) at 6 weeks after the initiation of treatment. At harvest ( 9 weeks after the initiation of treatment), 'Discovery Orange', 'Discovery Yellow', 'Taishan Gold', and 'Taishan Yellow' plants exhibited severe foliar salt damage with visual scores less than 2 (on a scale of 0 to 5 , with $0=$ dead and 5 = excellent with no foliar salt damage) in EC 6. In the same treatment, 'Hot Pak Gold' and 'Taishan Orange' plants all died and only one of nine 'Hot Pak Orange' and 'Hot Pak Yellow' plants survived. In EC 3, all cultivars had slight or minimal foliar salt damage with visual scores $\approx 4$ with the exception of Taishan Gold and Taishan Orange plants that showed moderate foliar damage with a visual score of 2.3 and 2.1, respectively. Treatment EC 3 reduced the flower number of 'Discovery Orange', 'Discovery Yellow', 'Hot Pak Gold', and 'Hot Pak Yellow' by $52 \%, 28 \%, 50 \%$, and $30 \%$, respectively, whereas EC 6 decreased the flower number of 'Discovery Orange' and 'Discovery Yellow' by $48 \%$ and $52 \%$, respectively. In addition, both EC 3 and EC 6 did not reduce total dry weight (DW) of any cultivars, except Hot Pak Yellow and Taishan Yellow. In conclusion, all marigold cultivars are moderately sensitive to salt. 'Discovery Orange', 'Taishan Yellow', 'Discovery Yellow', and 'Taishan Gold' were more tolerant than 'Hot Pak Gold', 'Hot Pak Orange', 'Hot Pak Yellow', and 'Taishan Orange'.

$\mathrm{W}$ ater scarcity is of major concern in the southwestern United States. Given this worry, it is remarkable that $62 \%$ of

This research was supported in part by the USDAARS Floricultural and Nursery Research Initiative and National Institute of Food and Agriculture Hatch project TEX090450

The content is solely the responsibility of the authors and does not necessarily represent the official views of the funding agencies. Mention of a trademark, proprietary product, or vendor does not constitute a guarantee or warranty of the product by the ASHS and does not imply its approval to the exclusion of other products or vendors that also may be suitable.

${ }^{1}$ Department of Plants, Soils and Climate, Utah State University, 4820 Old Main Hill, Logan, UT 84322

${ }^{2}$ Department of Horticultural Sciences, Texas A\&M AgriLife Research Center at El Paso, Texas A\&M University System, 1380 A\&M Circle, El Paso, TX 79927

${ }^{3}$ Texas A\&M AgriLife Research, Texas A\&M AgriLife Research and Extension Center at Overton, Texas A\&M University System, 1710 FM 3053 N, Overton, TX 75684

${ }^{4}$ USDA-ARS, 1680 Madison Avenue, Wooster, $\mathrm{OH}$ 44691

${ }^{5}$ Corresponding author. E-mail: gniu@ag.tamu.edu. https://doi.org/10.21273/HORTTECH03981-18 all freshwater is used for irrigation (Kenny et al., 2009). Alternative water sources such as brackish water, gray water, and reclaimed municipal water are becoming important resources for "new water" in arid to semiarid areas in the United States. Urban landscape irrigation with alternative waters to conserve potable water is common in water-scarce cities such as San Diego, CA, and Tucson, AZ (Grieve, 2011). However, this practice is still underused because high concentrations of salts in alternative waters can potentially stress, damage, and reduce plant growth if not managed properly (Niu and Cabrera, 2010). Water quality, specifically EC and harmful ions such as sodium $(\mathrm{Na})$ and chloride $(\mathrm{Cl})$, of alternative water also varies largely with the source of water and treatment method. The EC of reclaimed municipal water is usually two to three times higher than that of tap water (Niu and Cabrera, 2010). Maintaining a leaching fraction, monitoring salt concentration in alternative waters, improving drainage, and using salt-tolerant species are ways to avoid salt damage (Niu and Cabrera, 2010). More research on the salt tolerance of landscape plants is needed to prevent salt damage and maintain aesthetically appealing landscapes. To date, $\mathrm{Wu}$ and Dodge (2005) evaluated the salt tolerance of 86 tree species, 65 shrub species, 58 groundcover and vine species, and 57 grass species. More than 150 species and cultivars of landscape plants have been screened in greenhouse conditions at the Texas A\&M AgriLife Research and Extension Center in El Paso, TX. These studies demonstrate that landscape species and cultivars exhibited considerable differences in salt tolerance (Niu and Cabrera, 2010; Niu et al., 2011). More studies are essential to evaluate plant responses to salinity and to identify salt-tolerant plants for landscapes that are irrigated with alternative waters. Marigold, native to North and South America, is a genus of annual or perennial plants in the sunflower family (Asteraceae). Many marigold species have become naturalized around the world and are considered one of the most popular ornamental plants. Most marigold species have fine-textured, pinnate dark green leaves with golden, orange, yellow, and white flowers. French marigold is a short-stature plant, whereas african

\begin{tabular}{llll}
\hline $\begin{array}{l}\text { Units } \\
\text { To convert U.S. to SI, } \\
\text { multiply by }\end{array}$ & U.S. unit & SI unit & $\begin{array}{l}\text { To convert SI to U.S., } \\
\text { multiply by }\end{array}$ \\
\hline 10 & $\%$ & $\mathrm{~g} \cdot \mathrm{L}^{-1}$ & 0.1 \\
29.5735 & $\mathrm{fl} \mathrm{oz}$ & $\mathrm{mL}$ & 0.0338 \\
0.3048 & $\mathrm{ft}$ & $\mathrm{m}$ & 3.2808 \\
3.7854 & gal & $\mathrm{L}$ & 0.2642 \\
2.54 & inch(es) & $\mathrm{cm}$ & 0.3937 \\
6.4516 & inch & $\mathrm{cm}^{2}$ & 0.1550 \\
1 & mmho/cm & $\mathrm{dS} \cdot \mathrm{m}^{-1}$ & 1 \\
28.3495 & $\mathrm{oz}$ & $\mathrm{g}$ & 0.0353 \\
$\left({ }^{\circ} \mathrm{F}-32\right) \div 1.8$ & ${ }^{\circ} \mathrm{F}$ & ${ }^{\circ} \mathrm{C}$ & $\left({ }^{\circ} \mathrm{C} \times 1.8\right)+32$
\end{tabular}


marigold is a relatively taller plant (Valdez-Aguilar et al., 2009a). Many cultivars of both species are used as container plants in landscapes and as bedding plants. In addition, some cultivars of african marigold are excellent candidates for cut and dried flowers for the florist market (ValdezAguilar et al., 2009a). In the United States, an estimated $\$ 82$ million worth of marigold plants are sold annually as annual bedding and garden plants (U.S. Department of Agriculture, 2018). Numerous cultivars have been bred to offer different flower colors (golden, orange, yellow, and white flowers) and forms (erect growth or dwarf size) (PanAmerican Seed Co., 2018). For example, 'Discovery Orange' and 'Discovery Yellow' are dwarf african marigolds with a compact and tidy habit. 'Hot Pak Gold', 'Hot Pak Orange', and 'Hot Pak Yellow' are the first french marigold series with a mounded habit. They are heat-tolerant extra-dwarf plants bred to bloom all summer, even in the highest temperatures and humidity. 'Taishan Gold', 'Taishan Orange', and 'Taishan Yellow' are dwarf african marigolds and have a mounded and upright habit with $20 \%$ shorter peduncles and 15\% thicker stems. 'Taishan Gold', 'Taishan Orange', and 'Taishan Yellow' african marigolds were featured with spectacular performance in landscapes at the 2008 Olympic Games in Beijing, China (PanAmerican Seed Co., 2018).

'First Lady' african marigolds exhibited salt damage in a peat-perlite medium when the EC of a sodium chloride $(\mathrm{NaCl})$ and calcium chloride $\left(\mathrm{CaCl}_{2}\right)$ solution exceeded $7.9 \mathrm{dS} \cdot \mathrm{m}^{-1}$; therefore, it is rated as moderately tolerant to salinity (Huang and Cox, 1988). Villarino and Mattson (2011) also rated 'Crested Bonanza Bolero' french marigold as a moderately tolerant plant to salinity. Valdez-Aguilar et al. (2009a, 2009b) reported that the irrigation water $\mathrm{EC}(\mathrm{ECw})$ lower than $8 \mathrm{dS} \cdot \mathrm{m}^{-1}$ had minimal effects on the plant quality of 'Flagstaff' and 'Yellow Climax' african marigolds, and 'French Vanilla' french marigolds that are recommended for specialty cut flower production and for use in landscape sites as bedding plants. The fact that marigold plant species and cultivars with diversified salt tolerance are used in urban landscapes warrants further research. Additional, suitable cultivars should be identified for breeding and selecting salt-tolerant marigolds for landscape use in high soil salinity regions. The present study was designed to compare the growth of eight popular marigold cultivars when irrigated with saline solutions supplemented with $\mathrm{NaCl}$ and $\mathrm{CaCl}_{2}$.

\section{Materials and methods}

Plant materials and growing Conditions. On 20 Sept. 2016, marigold seedlings ('Discovery Orange', 'Discovery Yellow', 'Hot Pak Gold', 'Hot Pak Orange', 'Hot Pak Yellow', 'Taishan Gold', 'Taishan Orange', and 'Taishan Yellow') were received from the Texas A\&M University Agricultural Research and Extension Center at Overton (Overton, TX). The seedlings $(8.7 \pm 1.7 \mathrm{~cm}$ high $)$ were immediately transplanted into 6 -inch round green pots containing soilless growing substrate $[45 \%$ to $55 \%$ composted bark, canadian sphagnum moss, coir, perlite, and dolomite lime (Metro-Mix 560 SC; Sun Gro Horticulture, Agawam, MA)]. All plants were grown in a greenhouse in El Paso, TX (lat. $31^{\circ} 41^{\prime} 45^{\prime \prime} \mathrm{N}$, long. $106^{\circ} 16^{\prime} 54^{\prime \prime} \mathrm{W}$, elevation $1139 \mathrm{~m}$ ), and well irrigated with a reverse osmosis ( $\mathrm{RO})$ waterbased nutrient solution to avoid salt accumulation in the root zone until treatments started. The nutrient solution with an EC at $1.2 \mathrm{dS} \cdot \mathrm{m}^{-1}$ was prepared by adding $1 \mathrm{~g} \cdot \mathrm{L}^{-1} 15 \mathrm{~N}-$ $2.2 \mathrm{P}-12.5 \mathrm{~K}$ water-soluble fertilizer (Peters Excel 15-5-15 Cal-Mag Special; ICL Specialty Fertilizers, Dublin, $\mathrm{OH})$ to $\mathrm{RO}$ water. Two weeks after transplanting (3 Oct.), uniform plants were chosen and treatments were initiated. The average air temperature in the greenhouse was $24.1 \pm 5.9^{\circ} \mathrm{C}$ during the day and $15.3 \pm 4.1{ }^{\circ} \mathrm{C}$ at night. The average daily light integral was $5.1 \pm 1.5 \mathrm{~mol} \cdot \mathrm{m}^{-2} \cdot \mathrm{d}^{-1}$ and the average relative humidity was $43.5 \%$ $\pm 13.8 \%$ during the experiment.

Treatments. Saline solution at an EC of $3.0 \mathrm{dS} \cdot \mathrm{m}^{-1}$ (EC 3) was prepared by adding $0.60 \mathrm{~g} \cdot \mathrm{L}^{-1} \mathrm{NaCl}$ and $0.58 \mathrm{~g} \cdot \mathrm{L}^{-1} \mathrm{CaCl}_{2}$ to the aforementioned nutrient solution, and saline solution at $6.0 \mathrm{dS} \cdot \mathrm{m}^{-1}(\mathrm{EC} 6)$ was prepared by adding $1.65 \mathrm{~g} \cdot \mathrm{L}^{-1} \mathrm{NaCl}$ and $1.60 \mathrm{~g} \cdot \mathrm{L}^{-1} \mathrm{CaCl}_{2}$ to the nutrient solution. This mixture was used because $\mathrm{NaCl}$ is the most common salt in reclaimed municipal water (Niu and Cabrera, 2010) and $\mathrm{CaCl}_{2}$ forestalls potential calcium deficiencies (Carter and Grieve, 2006). Nutrient solution at an EC of $1.2 \mathrm{dS} \cdot \mathrm{m}^{-1}$ was used as the control. The $\mathrm{pH}$ of all solutions was adjusted to $6.1 \pm 0.4$. Both nutrient and saline solutions were prepared in 100-L tanks with confirmed EC using an EC meter (model B173; Horiba, Kyoto, Japan) before irrigation.

From 3 Oct. to 22 Nov., the treatment solutions were applied once per week, eight times total. At each irrigation, the plants were irrigated with $500 \mathrm{~mL}$ saline treatment solution per plant, resulting in a leaching fraction of $\approx 42.8 \% \pm 9.4 \%$. Between treatment solution irrigations, the plants were irrigated with nutrient solution whenever the substrate surface became dry. Irrigation frequency varied with environmental conditions and treatment solution. Plants at higher salinity used less irrigation because of presumed less water use resulting from reduced transpiration rates and leaf area.

Leachate EC. The leachate EC was determined following the pourthrough methods according to Cavins et al. (2008) and Wright (1986). In brief, a saucer was placed under the container which has drained for at least $30 \mathrm{~min}$ after the treatment solution was applied. A total of $100 \mathrm{~mL}$ distilled water was poured on the surface of the substrate to obtain $50 \mathrm{~mL}$ of leachate in the saucer. The leachate solution was collected and tested using an EC meter. One plant per treatment per cultivar was chosen for measurement. Leachate EC readings were averaged across cultivars.

FOLIAR SALT DAMAGE eVAluation. Foliar salt damage was rated for all plants by giving a visual score based on a reference scale from 0 to 5 , where $0=$ dead, $1=$ more than $90 \%$ foliar salt damage (salt damage: leaf burn, necrosis, and discoloration), $2=$ moderate $(50 \%$ to $90 \%)$ foliar salt damage, $3=$ slight (less than $50 \%$ ) foliar salt damage, $4=\operatorname{good}$ quality with minimal foliar salt damage, and $5=$ excellent without foliar salt damage (Sun et al., 2015). Foliar salt damage rating did not consider plant size.

LEAF RELATIVE CHLOROPHYLL CONTENT. Relative chlorophyll content [soil plant analysis development (SPAD) reading] was recorded using 
a handheld chlorophyll meter [measured as optical density (Minolta Camera Co., Osaka, Japan)] at the end of the experiment. Healthy and fully expanded leaves in the middle of shoots were chosen for measurement, and five plants per treatment per cultivar were measured.

Plant growth. Plant height (centimeters), from pot rim to the tallest plant growth point, was measured at the beginning and end (i.e., 30 Nov.) of the experiment. Two perpendicular widths (centimeters) were recorded for all plants. Growth index was calculated as (height + width $1+$ width 2$) / 3$. The number of flowers was also counted. At harvest, aboveground parts of all living plants were harvested. Leaf area was determined immediately using an area meter (LI-3100C; LI-COR Biosciences, Lincoln, NE). Flower and shoot DW was determined after ovendrying at $70{ }^{\circ} \mathrm{C}$ for $4 \mathrm{~d}$.

EXPERIMENTAL DESIGN AND STATISTICAL ANALYSIS. The experiment used a split-plot design with salinity treatment as the main plot and eight cultivars as subplot with nine replications per treatment per cultivar. Analysis of variance of all plant growth parameters was performed separately for each cultivar because several marigold cultivars in EC 6 were dead. Mean separation among treatments was conducted using Tukey's honestly significant difference multiple comparison at $\alpha=$ 0.05 . When plants in EC 6 treatment were dead, the mean comparison between control and EC 3 was analyzed by Student's $t$ test at $\alpha=0.05$.

Relative shoot DW (percent) was calculated for each plant in salt treatment as follows: shoot DW in salt treatment/shoot DW in control $\times$ 100. Similarly, relative growth index, relative leaf area, relative flower number, relative flower and total DW, and relative SPAD were calculated. These relative values and visual scores for foliar salt damage were used as salt tolerance indices for hierarchical cluster analysis (Zeng et al., 2002). The dendrogram and clustering of the eight marigold cultivars were obtained based on the Ward linkage method and squared Euclidean distance on the means of the salt tolerance indices for eight multivariate parameters, including all relative values and visual scores. All statistical analyses were performed using JMP (version 13.2; SAS Institute, Cary, NC).

\section{Results and discussion}

During the entire experimental period, the leachate solution had an EC range of $2.1-3.2 \mathrm{dS} \cdot \mathrm{m}^{-1}$ for the control (nutrient solution at an EC of $1.2 \mathrm{dS} \cdot \mathrm{m}^{-1}$ ) (Fig. 1). However, leachate solution EC increased from 3.5 to $5.7 \mathrm{dS} \cdot \mathrm{m}^{-1}$ for EC 3 and from 4.5 to $10.1 \mathrm{dS} \cdot \mathrm{m}^{-1}$ for EC 6 . These results are in line with previous works conducted by Niu and Rodriguez (2006), Niu et al. (2012), Sun et al. (2015), and Wu et al. (2016). These researchers consistently observed that the salinity level in the leachate solution increased gradually with multiple applications and was higher than that of the respective saline solutions after two or three irrigation events. These results indicate that salt accumulates in the plant root zone when they are irrigated with saline solution.

Marigold plants began to show foliar salt damage (leaf burn, necrosis, and discoloration) at 6 weeks after initiation of treatment (data not shown). At 9 weeks after initiation of treatment, all 'Hot Pak Gold' and 'Taishan Orange' plants in EC 6 died, whereas only one of nine 'Hot Pak Orange' and 'Hot Pak Yellow' plants survived in EC 6 with severe foliar salt damage (Table 1; Fig. 2). The remaining four cultivars in EC 6 experienced severe foliar salt damage with visual scores less than 2 . In EC 3 , 'Taishan Gold' and 'Taishan Orange' plants showed moderate foliar damage with a visual score of 2.3 and 2.1, respectively, whereas the remaining cultivars had slight or minimal foliar salt damage with visual scores $\approx 4$. Visual quality is an important parameter for evaluating the salt tolerance of flowering ornamental plants (Niu and Cabrera, 2010). High salinity causes plant injuries such as leaf necrosis, burn, and premature discoloration, which lead to poor visual quality and affect the marketability of ornamental plants. In this study, all 'Discovery Orange', 'Hot Pak Gold', and most of the 'Discovery Yellow', 'Hot Pak Orange', 'Hot Pak Yellow', and 'Taishan Yellow' plants in EC 3 had good visual quality, but this was not the case for all marigold plants in EC 6 .

Chlorophyll content is one of the important parameters to evaluate the salt tolerance of plant species (Santos, 2004). Salinity-induced chlorophyll degradation has been reported in previous studies in salt-sensitive plants (Niu et al., 2012; Sun et al., 2015; Wu et al., 2016). In this study, the relative chlorophyll content (SPAD reading) of all marigold plants grown in EC 3 was similar to that in the control (Table 1). 'Discovery Orange' and 'Taishan Gold' marigolds grown in EC 6 also had similar SPAD readings to those in the control and

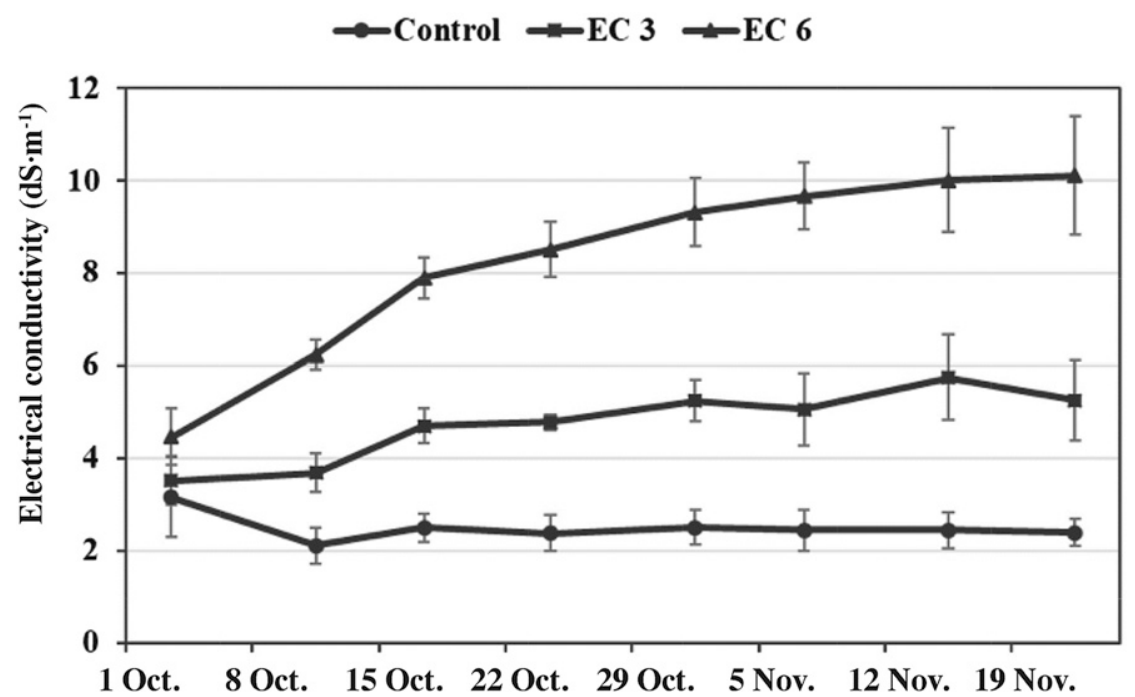

Fig. 1. Leachate electrical conductivity (EC) during the experimental period. Control represents nutrient solution at an EC of $1.2 \mathrm{dS} \cdot \mathrm{m}^{-1}$; EC 3 represents saline solution at an EC of $3.0 \mathrm{dS} \cdot \mathrm{m}^{-1}$; and EC 6 represents saline solution at an $\mathrm{EC}$ of $6.0 \mathrm{dS} \cdot \mathrm{m}^{-1}$. Vertical bars represent SD of the average of eight measurements, one per cultivar; $1 \mathrm{dS} \cdot \mathrm{m}^{-1}=1 \mathrm{mmho} / \mathrm{cm}$. 
Table 1. Visual score and relative chlorophyll content [soil plant analysis development (SPAD) reading] of eight marigold cultivars irrigated with nutrient solution [electrical conductivity $(\mathrm{EC})=1.2 \mathrm{dS} \cdot \mathrm{m}^{-1}$ (control)] or saline solution $\left[E C=3.0 \mathrm{dS} \cdot \mathrm{m}^{-1}(\mathrm{EC} 3)\right.$ or $\left.6.0 \mathrm{dS} \cdot \mathrm{m}^{-1}(\mathrm{EC} 6)\right]$ in a greenhouse. Plants were harvested after the eighth treatment ( 9 weeks after initiation of treatment). ${ }^{\mathrm{z}}$

\begin{tabular}{lccccccc}
\hline & \multicolumn{2}{c}{ Visual score (0 to 5 scale) } & & \multicolumn{3}{c}{ SPAD } \\
\cline { 2 - 4 } Cultivar & Control & EC 3 & EC 6 & & Control & EC 3 & EC 6 \\
\hline Discovery Orange & $5 \mathrm{a}^{\mathrm{x}}$ & $4.7 \mathrm{a}$ & $0.9 \mathrm{~b}$ & & $50.6 \mathrm{a}$ & $50.2 \mathrm{a}$ & $54.6 \mathrm{a}$ \\
Discovery Yellow & $5 \mathrm{a}$ & $3.8 \mathrm{a}$ & $1.2 \mathrm{~b}$ & & $54.7 \mathrm{a}$ & $53.1 \mathrm{a}$ & $42.5 \mathrm{~b}$ \\
Hot Pak Gold & $5 \mathrm{a}$ & $4.2 \mathrm{~b}$ & $0 \mathrm{c}$ & & $48.6 \mathrm{a}$ & $47.0 \mathrm{a}$ & $-{ }^{\mathrm{w}}$ \\
Hot Pak Orange & $5 \mathrm{a}$ & $3.3 \mathrm{~b}$ & $0.3^{\mathrm{w}}$ & & $50.5 \mathrm{a}$ & $50.4 \mathrm{a}$ & - \\
Hot Pak Yellow & $5 \mathrm{a}$ & $3.8 \mathrm{~b}$ & $0.1^{\mathrm{w}}$ & & $38.7 \mathrm{a}$ & $39.1 \mathrm{a}$ & - \\
Taishan Gold & $5 \mathrm{a}$ & $2.3 \mathrm{~b}$ & $0.7 \mathrm{~b}$ & & $46.5 \mathrm{a}$ & $48.9 \mathrm{a}$ & $39.4 \mathrm{a}$ \\
Taishan Orange & $5 \mathrm{a}$ & $2.1 \mathrm{~b}$ & $0 \mathrm{c}$ & & $47.1 \mathrm{a}$ & $48.0 \mathrm{a}$ & - \\
Taishan Yellow & $5 \mathrm{a}$ & $3.7 \mathrm{~b}$ & $1.7 \mathrm{c}$ & & $50.3 \mathrm{a}$ & $46.8 \mathrm{ab}$ & $40.6 \mathrm{~b}$ \\
\hline
\end{tabular}

${ }^{\mathrm{z}} 1 \mathrm{dS} \cdot \mathrm{m}^{-1}=1 \mathrm{mmho} / \mathrm{cm}$.

${ }^{\mathrm{y}} 0=$ dead $; \mathrm{l}=$ more than $90 \%$ foliar salt damage ( ( $50 \%$ to $90 \%$ ) foliar salt damage; $3=$ slight (less than $50 \%$ ) foliar salt damage; 4 = good quality with minimal foliar salt damage; and 5 = excellent without foliar salt damage.

${ }^{x}$ Means with same lowercase letters within a row and dependent variable are not significantly different among treatments by Tukey's honestly significant difference multiple comparison or between treatments by Student's $t$ test at $\alpha=0.05$.

wAll plants were dead or only one plant survived, and data were excluded for statistics.

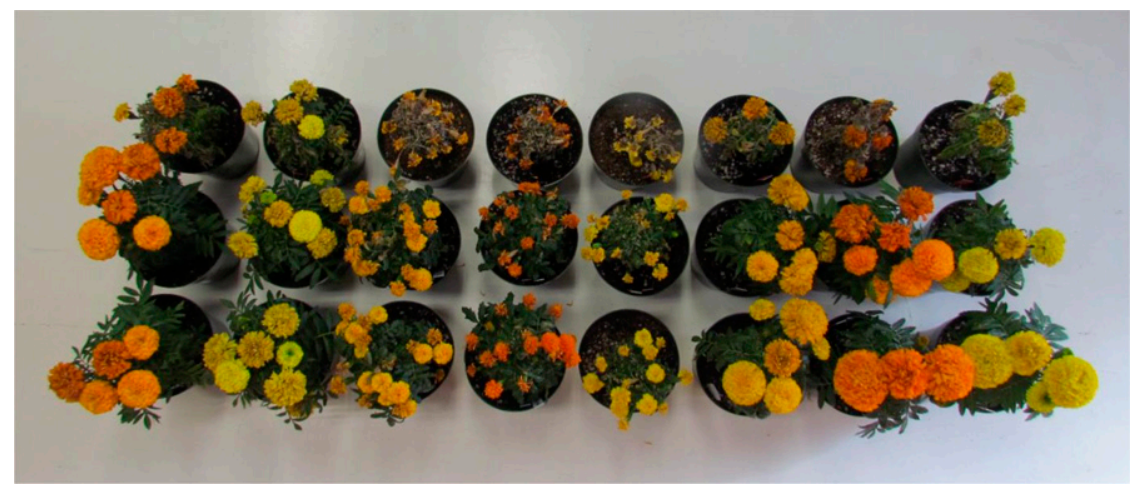

Fig. 2. A photograph of eight marigold cultivars taken at $58 \mathrm{~d}$ after initiation of treatment. Plants were irrigated with a nutrient solution at an electrical conductivity (EC) of 1.2 (control) or saline solutions at an EC of 3.0 or $6.0 \mathrm{dS} \cdot \mathrm{m}^{-1}$ (EC 3 or EC 6) once per week, eight times total. Cultivars from right to left: 'Taishan Yellow', 'Taishan Orange', and 'Taishan Gold' african marigolds; 'Hot Pak Yellow', 'Hot Pak Orange', and 'Hot Pak Gold' french marigolds; 'Discovery Yellow' and 'Discovery Orange' african marigolds. Treatments from bottom row to top: control, EC 3, and EC $6 ; 1 \mathrm{dS} \cdot \mathrm{m}^{-1}=1 \mathrm{mmho} / \mathrm{cm}$.

EC 3. However, the SPAD reading of 'Discovery Yellow' and 'Taishan Yellow' marigolds decreased compared with that of the control. Sayyed et al. (2014) also reported that african marigolds irrigated with $\mathrm{NaCl}$ solution had decreased chlorophyll and carotenoid contents determined by chemical extraction and using a spectrophotometer.

The growth indices of all marigold plants grown in the control did not differ from those in EC 3, with the exception of 'Hot Pak Orange' that had a $24 \%$ reduction in growth index (Table 2). In EC 6, 'Discovery Orange' still had a similar growth index to that in the control and EC 3 . The growth index of 'Discovery Yellow', 'Taishan Gold', and 'Taishan Yellow' in EC 6-grown marigold plants decreased by $60 \%, 59 \%$, and $41 \%$, respectively, compared with that of the control. Elevated salinity has been documented to slow plant growth in many herbaceous ornamental plants (Niu and Rodriguez, 2006; Niu et al., 2012; Sun et al., 2015; Wu et al., 2016). French marigold plants were shorter as the salinity of irrigation water increased (Bahmanzadegan and Aboutalebi, 2013). Valdez-Aguilar et al. (2009a) observed that 'French Vanilla' french marigolds and 'Flagstaff' and 'Yellow Climax' african marigolds exhibited a $20 \%$ to $30 \%$ decrease in plant height when irrigated with saline water at ECs of 4 and $6 \mathrm{dS} \cdot \mathrm{m}^{-1}$ and a $\mathrm{pH}$ of 6.4. Villarino Pizarro (2011) also reported that 'Crested Bonanza Bolero' french marigolds exhibited a significant reduction of $15 \%$ to $35 \%$ when irrigated for 5 weeks with saline solution with $\mathrm{NaCl}$ increasing from 20 to $80 \mathrm{~mm}$, compared with $0 \mathrm{~mm} \mathrm{NaCl}$.

All marigold plants in EC 3 had similar leaf areas to those in control (Table 2). In EC 6, 'Discovery Yellow' also had a similar leaf area to those in control and EC 3; however, compared with control, the leaf area of 'Discovery Orange', 'Taishan Gold', and 'Taishan Yellow' marigolds decreased by $70 \%, 56 \%$, and $68 \%$, respectively. Reduced leaf area has been observed in many plant species under salinity stress (Niu et al., 2012; Sun et al., 2015; Wu et al., 2016). This is a strategy plants use to adapt to a saline environment. As salinity lowers the water potential of the soil solution, and thereby makes water less available to plants, reducing leaf surface area with fewer stomata could reduce water loss significantly.

Flowers are a key feature for marigolds as an ornamental plant, so it is undesirable to have reduced flower numbers and quality in landscapes or containers. Treatment EC 3 reduced the flower number of 'Discovery Orange', 'Discovery Yellow', 'Hot Pak Gold', and 'Hot Pak Yellow' by $52 \%, 28 \%, 50 \%$, and $30 \%$, respectively, whereas treatment EC 6 decreased the flower number of 'Discovery Orange' and 'Discovery Yellow' by $48 \%$ and $52 \%$, respectively (Table 2). Although 'Hot Pak Orange', 'Taishan Gold', 'Taishan Orange', and 'Taishan Yellow' marigold plants had smaller flower number numerically, the differences were still not significant. These results are in agreement with a previous report (Valdez-Aguilar et al., 2009a) that 'Flagstaff' african marigolds had a 37\% and $24 \%$ decrease in flowering stems, whereas 'Yellow Climax' african marigold exhibited an $18 \%$ and $17 \%$ reduction in flowering stems, respectively, when irrigated with saline water at ECs of 4 and $6 \mathrm{dS} \cdot \mathrm{m}^{-1}$ and a $\mathrm{pH}$ of 6.4 .

All marigold plants grown in the control and EC 3 had similar flower 
Table 2. Growth index [(height + width $1+$ width 2)/3], leaf area, and number of flowers of eight marigold cultivars irrigated with nutrient solution [electrical conductivity $(\mathrm{EC})=1.2 \mathrm{dS} \cdot \mathrm{m}^{-1}$ (control)] or saline solution $\left[\mathrm{EC}=3.0 \mathrm{dS} \cdot \mathrm{m}^{-1}\right.$ (EC 3) or $6.0 \mathrm{dS} \cdot \mathrm{m}^{-1}$ (EC 6)] in a greenhouse. Plants were harvested after the eighth treatment (9 weeks after initiation of treatment). ${ }^{\mathrm{z}}$

\begin{tabular}{|c|c|c|c|c|c|c|c|c|c|}
\hline \multirow[b]{2}{*}{ Cultivar } & \multicolumn{3}{|c|}{ Growth index $(\mathrm{cm})^{\mathrm{z}}$} & \multicolumn{3}{|c|}{ Leaf area $\left(\mathrm{cm}^{2}\right)^{\mathrm{z}}$} & \multicolumn{3}{|c|}{ Flowers (no.) } \\
\hline & Control & EC 3 & EC 6 & Control & EC 3 & EC 6 & Control & EC 3 & EC 6 \\
\hline Discovery Orange & $7.9 \mathrm{a}^{\mathrm{y}}$ & $6.9 \mathrm{a}$ & $6.3 \mathrm{a}$ & $467 \mathrm{a}$ & $455 \mathrm{a}$ & $139 \mathrm{~b}$ & $23 \mathrm{a}$ & $11 \mathrm{~b}$ & $12 \mathrm{~b}$ \\
\hline Hot Pak Gold & $6.4 \mathrm{a}$ & $5.5 \mathrm{a}$ & $-^{x}$ & $385 \mathrm{a}$ & $376 \mathrm{a}$ & - & $44 \mathrm{a}$ & $22 \mathrm{~b}$ & - \\
\hline Hot Pak Orange & $7.0 \mathrm{a}$ & $5.3 \mathrm{~b}$ & - & $500 \mathrm{a}$ & $408 \mathrm{a}$ & - & $36 a$ & $27 \mathrm{a}$ & - \\
\hline Hot Pak Yellow & $6.1 \mathrm{a}$ & $5.7 \mathrm{a}$ & - & $121 \mathrm{a}$ & $98 \mathrm{a}$ & - & $23 \mathrm{a}$ & $16 \mathrm{~b}$ & - \\
\hline Taishan Yellow & $8.5 \mathrm{a}$ & $8.1 \mathrm{ab}$ & $5.0 \mathrm{~b}$ & $371 \mathrm{a}$ & $323 \mathrm{a}$ & $118 \mathrm{~b}$ & $13 \mathrm{a}$ & $11 \mathrm{a}$ & $9 \mathrm{a}$ \\
\hline
\end{tabular}

${ }^{\mathrm{z}} \mathrm{l} \mathrm{dS} \cdot \mathrm{m}^{-1}=1 \mathrm{mmho} / \mathrm{cm}, \mathrm{l} \mathrm{cm}=0.3937 \mathrm{inch}, 1 \mathrm{~cm}^{2}=0.1550 \mathrm{inch}^{2}$.

${ }^{y}$ Means with same lowercase letters within a row and dependent variable are not significantly different among treatments by Tukey's honestly significant difference multiple comparison or between treatments by Student's $t$ test at $\alpha=0.05$.

${ }^{\mathrm{x}}$ All plants were dead or only one plant survived, and data were excluded for statistics.

Table 3. Flower, shoot, and total dry weight (DW) of eight marigold cultivars irrigated with nutrient solution [electrical conductivity $(\mathrm{EC})=1.2 \mathrm{dS} \cdot \mathrm{m}^{-1}($ control $\left.)\right]$ or saline solution $\left[\mathrm{EC}=3.0 \mathrm{dS} \cdot \mathrm{m}^{-1}(\mathrm{EC} 3)\right.$ or $\left.6.0 \mathrm{dS} \cdot \mathrm{m}^{-1}(\mathrm{EC} 6)\right]$ in a greenhouse Plants were harvested after the eighth treatment (9 weeks after initiation of treatment). ${ }^{2}$

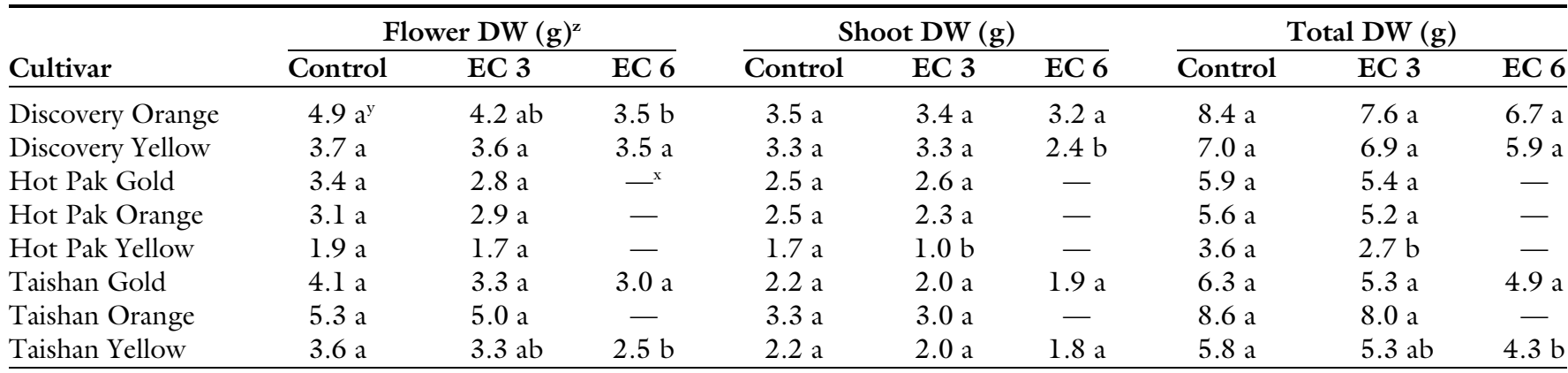

${ }^{\mathrm{z}} 1 \mathrm{dS} \cdot \mathrm{m}^{-1}=1 \mathrm{mmho} / \mathrm{cm}, \mathrm{lg}=0.0353 \mathrm{oz}$.

${ }^{y}$ Means with same lowercase letters within a row and dependent variable are not significantly different among treatments by Tukey's honestly significant difference multiple comparison or between treatments by Student's $t$ test at $\alpha=0.05$.

${ }^{\mathrm{x}}$ All plants were dead or only one plant survived, and data were excluded for statistics.

DW (Table 3). The flower DW of 'Discovery Orange' and 'Taishan Yellow' marigolds in EC 6 was reduced by $29 \%$ and $31 \%$, respectively, compared with that of the control, but that of 'Discovery Yellow' and 'Taishan Gold' did not change. Similarly, 'French Vanilla' french marigolds exhibited a $13 \%$ to $26 \%$ decrease in flower DW when irrigated with saline water at ECs of 4 and $6 \mathrm{dS} \cdot \mathrm{m}^{-1}$ and a $\mathrm{pH}$ of 6.4 , and 'Yellow Climax' and 'Flagstaff' african marigolds had a $50 \%$ to $65 \%$ decrease in flower DW (Valdez-Aguilar et al., 2009a).

Both treatments EC 3 and EC 6 did not reduce the shoot DW of all cultivars, except that Hot Pak Yellow in EC 3 had $41 \%$ less shoot DW and Discovery Yellow in EC 6 exhibited $27 \%$ less shoot DW than the respective control (Table 3 ). The total DW of all marigold plants grown in EC 3 was not different from that in control

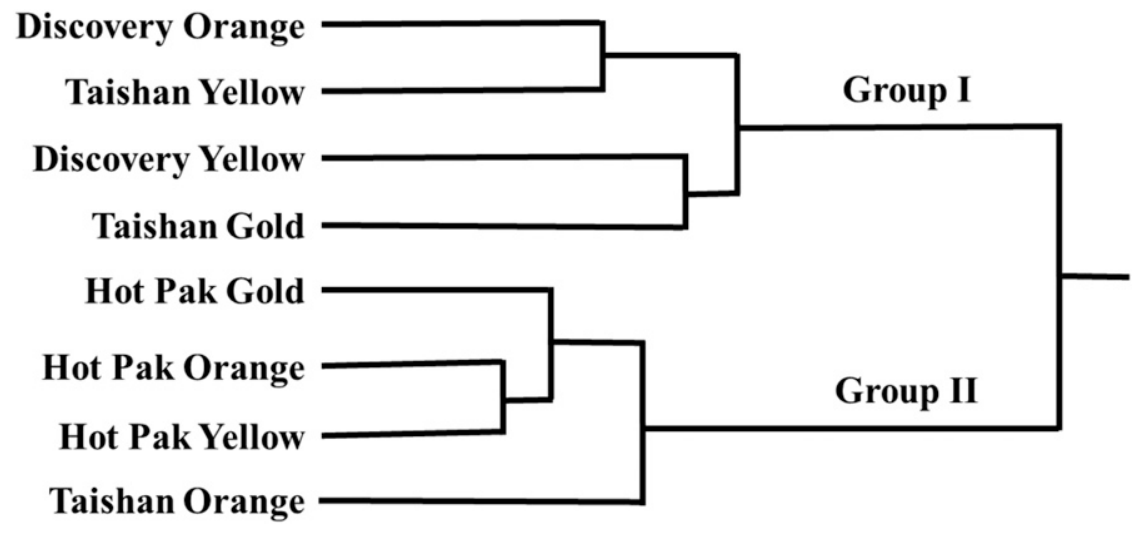

Fig. 3. Cluster analysis of the salt tolerance of eight marigold cultivars. The relative growth index; relative leaf area; relative flower number; relative flower, shoot, and total dry weight; relative soil plant analysis development reading; and visual score of marigold plants irrigated with saline solution at electrical conductivities (ECs) of $3.0 \mathrm{dS} \cdot \mathrm{m}^{-1}(\mathrm{EC} \mathrm{3})$ and $6.0 \mathrm{dS} \cdot \mathrm{m}^{-1}$ (EC 6) were used as salt tolerance indices for hierarchical cluster analysis. The dendrogram was obtained based on the Ward linkage method and squared Euclidean distance on the means of the salt tolerance indices for the aforementioned eight multivariate parameters. Group I was relatively more tolerant than group II to salinity in this study; $1 \mathrm{dS} \cdot \mathrm{m}^{-1}=$ $1 \mathrm{mmho} / \mathrm{cm}$. 
with an exception of 'Hot Pak Yellow', which had a $25 \%$ reduction in total DW. 'Taishan Yellow' marigold in EC 6 also had a 26\% reduction in total DW, whereas the total DW of 'Discovery Orange', 'Discovery Yellow', and 'Taishan Gold' did not change. In previous reports, when marigold plants were irrigated with saline water at ECs of 4 or $6 \mathrm{dS} \cdot \mathrm{m}^{-1}$ and a $\mathrm{pH}$ of 6.4 , 'French Vanilla' french marigolds had $21 \%$ to $32 \%$ decrease in shoot DW, whereas 'Flagstaff' and 'Yellow Climax' african marigolds had $53 \%$ to $65 \%$ reduction in shoot DW, respectively (ValdezAguilar et al., 2009a). 'Crested Bonanza Bolero' french marigolds had $32 \%, 46 \%, 67 \%$, and $88 \%$ less DW when they were irrigated for 5 weeks with $20,40,60$, and $80 \mathrm{~mm} \mathrm{NaCl}$, respectively (Villarino Pizarro, 2011).

A hierarchical cluster analysis was conducted using eight multivariate parameters including visual score, relative growth index, leaf area, flower number, flower DW, shoot DW, total DW, and SPAD of marigold plants irrigated with saline solution at EC 3 and EC 6 . Based on the Ward linkage method and squared Euclidean distance on the means of the salt tolerance indices for the eight multivariate parameters, the dendrogram shows two distinguishable clusters (Fig. 3). The first cluster of 'Discovery Orange', 'Taishan Yellow', 'Discovery Yellow', and 'Taishan Gold' is considered more salt tolerant than the second cluster of 'Hot Pak Gold', 'Hot Pak Orange', 'Hot Pak Yellow', and 'Taishan Orange'.

In conclusion, all marigold cultivars are moderately sensitive to salinity. In EC 6, all 'Hot Pak Gold' and 'Taishan Orange' marigolds died, whereas only one of nine 'Hot Pak Orange' and 'Hot Pak Yellow' plants survived and all other survived marigold cultivars experienced severe foliar salt damage. Even in EC 3, 'Taishan Gold' and 'Taishan Orange' marigolds had moderate foliar damage. Among all tested marigold cultivars, Discovery Orange, Taishan Yellow, Discovery Yellow, and Taishan Gold were relatively more tolerant than the remaining four cultivars to the salinity of irrigation water in this study. These results might be helpful for marigold breeders as they are interested in breeding salt-tolerant marigold cultivars for landscapes with high soil salinity.

\section{Literature cited}

Bahmanzadegan, M.J. and A. Aboutalebi. 2013. Interaction between ammonium nitrate and salinity on germination rate and vegetative growth of French marigold (Tageta patula). Intl. Res. J. Appl. Basic Sci. 5(10):1312-1317.

Carter, C.T. and C.M. Grieve. 2006. Salt tolerance of floriculture crops, p. 279-287. In: M.A. Khan and D.J. Weber (eds.). Ecophysiology of high salinity tolerant plants. Springer Science+Business Media, Dordrecht, The Netherlands.

Cavins, T.J., B.E. Whipker, and W.C. Fonteno. 2008. Pourthru: A method for monitoring nutrition in the greenhouse. Acta Hort. 779:289-298.

Grieve, C.M. 2011. Review irrigation of floricultural and nursery crops with saline wastewaters. Isr. J. Plant Sci. 59(2-4):187196.

Huang, Z.T. and D.A. Cox. 1988. Salinity effects on annual bedding plants in a peat-perlite medium and solution culture. J. Plant Nutr. 11(2):145-159.

Kenny, J.F., N.L. Barber, S.S. Hutson, K.S. Linsey, J.K. Lovelace, and M.A. Maupin. 2009. Estimated use of water in the United States in 2005. U.S. Geol. Surv. Circ. 1344:52.

Niu, G. and R.I. Cabrera. 2010. Growth and physiological responses of landscape plants to saline water irrigation: A review. HortScience 45:1605-1609.

Niu, G. and D.S. Rodriguez. 2006. Relative salt tolerance of selected herbaceous perennials and groundcovers. Scientia Hort. 110(4):352-358.

Niu, G., R. Cabrera, T. Starman, and C. Hall. 2011. Water conservation team in ornamental crops through the use of alternative water sources. HortTechnology 21:694-695.

Niu, G., M. Wang, and D. Rodriguez. 2012. Response of zinnia plants to saline water irrigation. HortScience 47:793-797.

PanAmerican Seed Co. 2018. Taishan ${ }^{\circledR}$ Gold African marigold. 6 Jan. 2018. <https://www.panamseed.com/plant_ info.aspx?phid=040705575002119>.
Santos, C.V. 2004. Regulation of chlorophyll biosynthesis and degradation by salt stress in sunflower leavesScientia Hort.10319399.

Sayyed, A., H. Gul, Z. Ullah, and M. Hamayun. 2014. Effect of salt stress on growth of Tagetes erecta L. Pakhtunkhwa J. Life Sci.2(3/4):96106.

Sun, Y., G. Niu, and C. Perez. 2015. Relative salt tolerance of seven Texas Superstar ${ }^{\circledR}$ perennials. HortScience 50:1562-1566.

U.S. Department of Agriculture. 2018. 2014 census of horticultural specialties, Table 4. 6 Jan. 2018. <https://www. agcensus.usda.gov/Publications/2012/ Online_Resources/Census_of Horticulture_Specialties/hortic_1_004_ 004.pdf>.

Valdez-Aguilar, L., C. Grieve, and J. Poss. 2009a. Salinity and alkaline $\mathrm{pH}$ in irrigation water affect marigold plants: I. Growth and shoot dry weight partitioning. HortScience 44:1719-1725.

Valdez-Aguilar, L., C. Grieve, and J. Poss. 2009 b. Salinity and alkaline $\mathrm{pH}$ in irrigation water affect marigold plants: II. Mineral ion relations. HortScience 44:17261735 .

Villarino, G.H. and N.S. Mattson. 2011. Assessing tolerance to sodium chloride salinity in fourteen floriculture species. HortTechnology 21:539-545.

Villarino Pizarro, G.H. 2011. Salt tolerance in floriculture species: Characterization of salt tolerance and the cloning of a novel petunia gene involved in the trehalose sugar biosynthesis (trehalose-6phosphate synthase I) and evaluate its potential role as a stress osmolyte in $\mathrm{mu}-$ tant yeasts. Cornell Univ., Ithaca, NY, MS Diss.

Wright, R.D. 1986. The pour-through nutrient extraction procedure. HortScience 21:227-229.

Wu, L. and L. Dodge. 2005. Landscape plant salt tolerance selection guide for recycled water irrigation. 6 Jan. 2018. $<$ ht tp://slosson.ucdavis.edu/ Landscape_Plant_Selection_Guide_for_ Recycled_Water_Irrigation/>.

Wu, S., Y. Sun, G. Niu, L.G.P. Graciela, and C.R. Arturo. 2016. Responses of six Lamiaceae landscape species to saline water. J. Environ. Hort. 34(1):30-35.

Zeng, L., M.C. Shannon, and C.M. Grieve. 2002. Evaluation of salt tolerance in rice genotypes by multiples agronomic parameters. Euphytica 127(2):235-245. 